This is a peer-reviewed, accepted author manuscript of the following research chapter: Mattes, R. (2018). Support for democracy. In W. Thompson (Ed.), Oxford Research Encyclopedia in Politics (Oxford Research Encyclopaedias). [New York]: Oxford University Press. https://doi.org/10.1093/acrefore/9780190228637.013.622

\title{
SUPPORT FOR DEMOCRACY
}

Robert Mattes

\section{Summary}

With the worldwide wave of democratization, scholars interested in the preservation of these new democracies dusted off old theories of regime maintenance. While commonly based on the assumption that democracy requires democrats, researchers proceeded in different directions, depending on their image of the ideal democrat. Four decades later, we now know a great deal about who supports democracy, and why. However, the state of our knowledge is incomplete at the point where it matters the most. As might be expected in any emerging area of research, different sets of scholars based their research instruments on contrasting understandings of what it means to be a democrat, and how democrats are best identified and measured. More importantly, they proceeded from differing understandings and under-specified theories as to why democrats are important, how many are needed, and how they actually affect the level and stability of democracy. Thus, while the intuition that democracy requires democrats is strong, the actual state of our evidence is still mixed, at best.

\section{Keywords}

Public Opinion, Public Support, Democracy, Democratization, Democratic Consolidation 
This is a peer-reviewed, accepted author manuscript of the following research chapter: Mattes, R. (2018). Support for democracy. In W. Thompson (Ed.), Oxford Research Encyclopedia in Politics (Oxford Research Encyclopaedias). [New York]: Oxford University Press. https://doi.org/10.1093/acrefore/9780190228637.013.622

\section{Democracy Requires Democrats}

With the worldwide wave of democratization beginning in 1974 and escalating after 1989, scholars interested in identifying the factors most likely to preserve these new democracies began to dust off old theories of regime maintenance which had identified the fundamental importance of citizen attitudes and values. Based largely, if implicitly on these approaches, a new and extensive body of public opinion research then developed. For all its internal differences, this research is based on the assumption that -- besides committed elites and well-functioning political institutions -- ordinary citizens are a key part of the democratic equation. Democracy, in other words, requires democrats. Or as Richard Rose and his colleagues (1998: 8), put it:

If institutions are the 'hardware' of democracy, then what people think about these institutions constitutes the 'software' of democracy - and software is just as important as hardware in making a system work...[C]onstitutional reforms are lifeless or irrelevant if they do not have the support of the people.

Beginning with the very first analyses of these transitions to democracy, various teams of scholars carried out a wide range of public opinion projects in the new multi-party systems of Southern Europe (Gunther et al 1986; Morlino and Montero 1995), Latin America ( Booth and Seligson, 1994; Lagos 1997), Central and Eastern Europe (Evans and Whitefeld 1995; Barnes and Simon 1998; Rose et al., 1998), the Soviet Union (Gibson et al., 1992; Finifter and Mickiewicz, 1992; Miller et al., 1993), East Asia (Dalton and Shin 2006; Chu et al. 2008), SubSaharan Africa (Bratton et al., 2005), South Asia (de Souza et al., 2008), and North Africa and the Middle East (Jamal and Tessler 2008). Ongoing global survey projects, such as the World Values Survey, also re-tooled their questionnaires to include new items on democracy. While they frequently differed in approach, virtually all of these studies assessed the extent of favorable citizen attitudes toward democracy, and the factors that led people living in new, potentially fragile democracies to embrace democratic values, institutions and processes.

Through this body of research, we now know a great deal about who supports democracy, and why. However, the state of our knowledge is incomplete at the point where it matters the most. As might be expected in any emerging area of research, different sets of scholars based their research instruments on contrasting understandings of what it means to be a democrat, and 
This is a peer-reviewed, accepted author manuscript of the following research chapter: Mattes, R. (2018). Support for democracy. In W. Thompson (Ed.), Oxford Research Encyclopedia in Politics (Oxford Research Encyclopaedias). [New York]: Oxford University Press. https://doi.org/10.1093/acrefore/9780190228637.013.622

how democrats are best identified and measured (also see Shin ORE). More importantly, scholars proceeded from differing understandings and under-specified theories as to why democrats are important, how many are needed, and how they actually affect the level and stability of democracy. Thus, while the intuition that democracy requires democrats is strong, the actual state of our evidence is still mixed, at best.

\section{What Kind of Democrat?}

More than half a century ago, David Easton (1957) proposed that a political system would maintain itself only when it established an equilibrium between the "inputs" generated by society and the "outputs" delivered by that system. Societal inputs comprise not only a vast range of "demands," consisting of what society's members want the system to do (or not do), but also "supports" offered by members of society, consisting of cooperative or assistive actions or favorable orientations. One type of support is offered by members of society on an instrumental basis when they are satisfied with what they get from the system (the "outputs"). He called this "specific support". However, because virtually all political systems encounter periods of stress caused by economic recession or political scandal, they would not last very long if they were based only on this type of support. Thus, Easton reasoned that there must also be a form of support based not on short, or even medium-term satisfaction, but on a belief that the existing system of making, executing, and enforcing societal rules is legitimate - or what he called "diffuse support." For a political regime, widespread diffuse support would consist of an attitudinal consensus around the fundamental "rules of the game" that provides a "reserve of support that enables a system to weather the many storms when outputs cannot be balanced off against input of demands. It is kind of support that a system does not have to buy with more or less direct benefits." (Easton 1975: 273).

Easton's theory, however, tells us only that a political system needs diffuse support; it does not consider the nature of those attitudes, or the nature of the political system. Thus, public opinion scholars have also linked their work to a related argument advanced by Harry Eckstein $(1966,1961)$. Eckstein hypothesized that the success of a given system depended on the 
This is a peer-reviewed, accepted author manuscript of the following research chapter: Mattes, R. (2018). Support for democracy. In W. Thompson (Ed.), Oxford Research Encyclopedia in Politics (Oxford Research Encyclopaedias). [New York]: Oxford University Press. https://doi.org/10.1093/acrefore/9780190228637.013.622

"congruence" of its specific basic operating principles and current popular values. In other words, particular regimes require particular political cultures; or in the converse, some particular cultures are unsuitable to support particular regimes. Thus, Eckstein reminds us that the content of that culture matters. "Congruence theory" sees the waves of democratization that began in the 1970s as the consequence of a disjuncture between the norms of the old regime and its institutions, and those of the mass public. The key research question in new democracies is whether the value structure that questioned and de-legitimated the former authoritarian or totalitarian regime is sufficient to legitimate and consolidate the new democracy.

The congruence argument, however, also has important shortcomings. It does not tell us much about the content of the values that are congruent with a democratic system. In other words, if a democracy requires democrats, what kind of democratic citizen is needed? A review of the most important contributions to the literature reveals at least four distinct conceptions, or images of the kind of democrat needed to sustain democracy and make it work. The first three emphasize different types of values, while the fourth focusses on the role of regime preferences.

\section{Mrs. Dahl?}

Scholars falling within the first tradition have focused on identifying and measuring a set of basic psychological predispositions or personality attributes conducive to democracy, which when combined together might make up a composite ideal citizen. We could call this citizen “Mrs. Dahl”. In Polyarchy (1970) and in Democracy and Its Critics (1989), Robert Dahl argued that democracy (or his term for modern representative democracy "polyarchy") depends on a distinctive set of citizen beliefs (held at least by the most active citizens): the effectiveness of government in solving major problems, the legitimacy of democratic institutions and participation, competition combined with the possibility of cooperation with other citizens, democratic authority relationships between government and governed, and trust in political leaders and fellow citizens.

A long line of important political culture studies has embodied this approach, including Gabriel Almond and Sydney Verba's (1963) foundational study of political culture and democracy, and studies by Eckstein (1966), Lucien Pye and Verba (1965), and Alex Inkeles and 
This is a peer-reviewed, accepted author manuscript of the following research chapter: Mattes, R. (2018). Support for democracy. In W. Thompson (Ed.), Oxford Research Encyclopedia in Politics (Oxford Research Encyclopaedias). [New York]: Oxford University Press. https://doi.org/10.1093/acrefore/9780190228637.013.622

David Smith (1974). While these works were produced at different times, they all focus on psychological or personality attributes, including moderation, accommodation, tolerance, pragmatism, interpersonal trust, efficacy, cooperation, and willingness to compromise. Dahl's work was an even more explicit influence on Gibson et al.'s study of political attitudes in the Soviet Union of the late 1980s. They defined a democrat as someone:

who believes in individual liberty and who is politically tolerant, who holds a certain amount of distrust of political authority but at the same time is trustful of fellow citizens, who's obedient but nevertheless willing to assert rights against the state, who views the state as constrained by legality, and who supports basic democratic institutions and processes (Gibson et al. 1992: 372).

The typical research design used in this approach consists of a series of questions that ask respondents to agree or disagree with statements about democracy, democratic processes and politics more broadly. Gibson, for instance, used 19 different items to measure six subdimensions of democratic values: tolerance, valuation of liberty (versus order), willingness to assert rights / rights consciousness, support for dissent, support for independent media, and support for democratic elections, and found that these attitudes cohere into a general syndrome of democratic beliefs (Gibson et al. 1992).

\section{Mr. Putnam?}

A second image of the kind of democrat required by democracy focuses on the element of interpersonal trust contained in the Dahlian framework, but adds a specific set of social structure and behaviors related to civic associations. Based on Robert Putnam's (1993) Making Democracy Work, the ideal democrat is not someone with a democratic personality, but a "socially capitalized man." Social capital consists of connections amongst citizens which create norms of cooperation and trust, and together constitute a resource on which people and communities can draw for public benefit. Thus, "Mr. Putnam" is a person with a deep sense of trust in his fellow citizens, and who belongs to and is involved in multiple community organizations.

In contrast to the Dahlian approach, Putnam's theory is a macro, rather than micro level theory. As Norris (2002: XXX) puts it, "we can be higher or lower in social capital, but not you 
This is a peer-reviewed, accepted author manuscript of the following research chapter: Mattes, R. (2018). Support for democracy. In W. Thompson (Ed.), Oxford Research Encyclopedia in Politics (Oxford Research Encyclopaedias). [New York]: Oxford University Press. https://doi.org/10.1093/acrefore/9780190228637.013.622

or I." Thus, a socially capitalized society is characterized by a dense matrix of civic organizations in which citizens have overlapping membership, and an extensive sense of interpersonal trust which creates a resource on which neighborhoods, communities and countries can draw to "make democracy work." In particular, social capital helps produce public goods and solve the "free rider" problem, particularly in the area of collective action. Norms of cooperation and trust "spill over" into forms of civic participation such as working with others, contacting representatives, and monitoring government. All of these activities make government more accountable, help government bodies such as the police or social welfare services do their jobs, or even help provide services when officials structures do not work.

While specific country studies experimented with ways to measure interpersonal trust as a multifaceted concept with multi-item scales. Longitudinal analysis of social capital in the United States and comparative cross-national studies have tended to rely on the widely critiqued single standard item on generalized interpersonal trust in "others." ${ }^{1}$ This question was asked in the U.S. as early as 1972, and subsequently included in many other opinion studies, as were other typical questions on membership in a range of civic associations and groups. ${ }^{2}$

\section{Mrs. Maslow?}

The third image of the ideal democrat retains the focus on interpersonal trust, but embeds it within a broader range of attitudes variously called "post-modern," "self-expression," "liberty," or "emancipation" values. Based fundamentally on the work of Ronald Inglehart, this approach proceeds from an attempt to provide a deeper theoretical basis to the longstanding claim of modernization scholars that economic growth, increasing levels of education, and an expanding network of communication, push political systems toward liberalization and democracy in a uniform way.

Inglehart identified two key mechanisms by which economic change leads to political change. First, the "scarcity hypothesis" contends that people value that which is in least supply. Pointing to Abraham Maslow's (1943) idea of a "hierarchy of needs," Inglehart argued that where people encounter regular shortages of basic survival needs, they will focus little if any attention on the form of government, and support any political system that seemes to meet those 
This is a peer-reviewed, accepted author manuscript of the following research chapter: Mattes, R. (2018). Support for democracy. In W. Thompson (Ed.), Oxford Research Encyclopedia in Politics (Oxford Research Encyclopaedias). [New York]: Oxford University Press. https://doi.org/10.1093/acrefore/9780190228637.013.622

needs. Only when, and where people's basic and intermediate physiological security needs have been satisfied will they come to emphasize "higher order" needs, or what Maslow called "selfactualization," such as a clean environment, racial and gender equality, sexual emancipation, free speech, liberty and democracy. Second, the "socialization hypotheses" asserts that people's fundamental values are learned during adolescence, solidify in early adulthood, and change only modestly thereafter. The simple linear view of modernization and democratization might conclude that the reason wealthier countries are more democratic is that people adopt more democratic values as they become wealthier. But the socialization mechanism means that developing societies will democratize only once they have a sufficiently large number of citizens who have grown up free of material need. Thus, while economic change drives value change, the key differences within a country will occur between generations.

Inglehart challenged the linear view of early modernization theory in another way. Joined by Christian Welzel, he concluded that because the shift from traditional to industrial economies leads to greater hierarchy, bureaucratization, centralization of authority, and a shift from traditional to secular values, modernization can lead either to democracy or totalitarianism (e.g. Germany, Italy, Soviet Union). Rather, it is the shift from industrial to post-industrial service economies that generates greater emphasis on individual autonomy and self-expression values and produces a sufficiently widespread number of "self-actualized" democrats who not only demand democracy but also make democracy work through increased rates of political participation, often featuring new or unconventional forms.

Measured through a variety of question items and scales from the World Values Survey originally designed to measure older concepts of "materialism" and "post-materialism," Inglehart and Welzel's many publications presented critics with a moving target as their scales of selfexpression and emancipation values changed rapidly, if marginally. However, at its core, the "self-actualized" person was generally someone who is happy and satisfied a with life, trusts other people, values equality over patriarchy, participation over physical or economic security, and tolerance over conformity. However, while Inglehart is interested in creating national level indices that describe the extent of self-expression or emancipation values, scholars have raised a 
This is a peer-reviewed, accepted author manuscript of the following research chapter: Mattes, R. (2018). Support for democracy. In W. Thompson (Ed.), Oxford Research Encyclopedia in Politics (Oxford Research Encyclopaedias). [New York]: Oxford University Press. https://doi.org/10.1093/acrefore/9780190228637.013.622

steady chorus of criticism oft the micro-level structure of these macro-level indices (see Seligson 2002; Teorell and Hadenius 2006; Lane and Wagschal 2012; Alemán and Woods 2016).

\section{Mr. Churchill?}

While the first three approaches built upon one another, to some extent, the fourth approach marks a significant departure. Rather than attempting to identify and measure values conducive to democracy, it focuses on popular regime preferences. Richard Rose (1997) criticized the previous approaches by asking whether there was any reason to expect to find large numbers of citizens with democratic personalities, high levels of social capital, or self-actualization in the new democracies of the 1990s. In contrast to what they called the "idealist" value based approach, Rose and William Mishler (2001) proposed a more limited, "realist" theory of democracy and public opinion. That is, the ideal citizen in a new democracy is not someone who love's democracy, or is democratic in personality, but more simply who sees democracy as the least bad alternative. This is what Rose called the "Churchill hypotheses," a play on Churchill's famous 1947 address to the British House of Commons in which he observed: "No one pretends that democracy is perfect or all wise. Indeed, it has been said that democracy is the worst form of Government except all those other forms that have been tried from time to time." Thus, their image of the ideal, or at least sufficient democrat required in a new democracy is "Mr.

Churchill." And support for democracy is conceived not as the holding of particular values but as a choice between competing regime types.

This approach gained wide appeal because it also cohered well with Juan Linz and Alfred Stepan's influential study of democratization (1996: 14-15) in which they built public opinion into their definition of a consolidated democracy. Besides the absence of anti-democratic or secessionist groups, and the presence of universal adherence to democratic norms and practices, democracy becomes consolidated, they argued, only "when a strong majority of public opinion...holds the belief that democratic procedures and institutions are the most appropriate way to govern collective life, and when support for anti-system alternatives is quite small or more-or-less isolated from pro-democratic forces." That is, consolidation occurs when democracy becomes "the only game in town" (p. 6). However, as appealing as this definition was 
This is a peer-reviewed, accepted author manuscript of the following research chapter: Mattes, R. (2018). Support for democracy. In W. Thompson (Ed.), Oxford Research Encyclopedia in Politics (Oxford Research Encyclopaedias). [New York]: Oxford University Press. https://doi.org/10.1093/acrefore/9780190228637.013.622

for public opinion researchers, it was not completely satisfying since Linz and Stepan failed to specify how much support was enough, though Diamond (1999) provided a degree of greater precision reckoning that consolidation required support from "all significant elites," and 75 percent of the mass public.

Rather than enquiring how close or distant people fall from some ideal state of mind, the measurement strategy in this approach asks respondents about alternative regimes, especially those with which they have had some actual experience. And rather than requiring respondents to agree or disagree with statements about democracy, the typical research strategy frames questions so as to offer respondents explicit alternatives to democracy. Perhaps the most widely used question, first asked in surveys in Southern Europe (Morlino and Montero 1995), offers respondents three distinct statements to the effect that "democracy is always preferable," an "authoritarian" or "non-democratic regime is sometimes preferable," or "it doesn't matter to a person like me."3 These types of questions are often complemented by, or combined with questions on alternative non-democratic regimes. The original formulation began by telling respondents that "Our current system of government is not the only one that this country has had," and then asked them whether they supported or opposed various non-democratic alternatives. ${ }^{4}$ Question items based on the Churchillian approach now constitute the backbone of the measurement of support for democracy of the various regional Barometer surveys, also known as Global Barometer Surveys (see Denemark et al. 2016). It is also important to note that a set of questions apparently framed in this approach was built into the World Values Survey. However, as we will see, slight differences in how these items were framed and worded have produced drastically differing results.

\section{Satisfied Democrats?}

It is worthwhile to take note of one additional line of analysis which focusses on the results to a question on "satisfaction with democracy." Properly understood, this or similar questions provides a useful measure of popular evaluations of the political and economic performance of the democratic system (or what Easton would have called "outputs"). Indeed, support and satisfaction with democracy have distinct empirical etiologies (Mattes and Bratton 
This is a peer-reviewed, accepted author manuscript of the following research chapter: Mattes, R. (2018). Support for democracy. In W. Thompson (Ed.), Oxford Research Encyclopedia in Politics (Oxford Research Encyclopaedias). [New York]: Oxford University Press. https://doi.org/10.1093/acrefore/9780190228637.013.622

2007), and distinct consequences (Gunther and Montero 2007). However, while no scholar has used this item as an indicator of diffuse regime support, many have used it as a measure of Easton's notion of "specific support" specifically, or as a form of legitimacy more broadly (e.g. Fuchs et al, 1995; Anderson et al. 2005; Listhaug et al. 2009; Aarts et al. 2014; Aarts et al. 2016).

This assumes that satisfaction is indicative of a supportive attitude. However, the use of this item to tap specific regime support conflates evaluations of regime performance with regime support, defined as the belief in the desirability of democracy as a regime. Whether support for democracy is specific or diffuse cannot be ascertained prima facie by a face validity reading of question wording, but rather through the statistical analysis of the co-variation of stated support and performance evaluations. That is, just because a large number of respondents choose the response that "democracy is always preferable," does not mean on its face that the society is composed of a large number of steadfast democrats who value democracy intrinsically. If prodemocratic responses vary instrumentally in a systematic way with expressed satisfaction with "the way democracy works," or with evaluations of presidential performance, satisfaction with the economy, or partisanship, that support is "specific" in the Eastonian sense. Conversely, if expressed support is unlinked to performance evaluations, and rather to other sociological factors, such as education, cognitive sophistication, that support can be seen as "diffuse" in the sense that those people support democracy intrinsically.

Thus, questions on satisfaction with democracy, or any other evaluations of the performance of democratic institutions have a clear role to play as indicators of output satisfaction, or what I have called in my work with Michael Bratton, the "supply of democracy" (Bratton et al 2005; Mattes and Bratton 2007). But they should not be used as a measure of support, whether diffuse or specific. Indeed, while this literature assumed that positive replies indicated specific support, negative replies (when combined with democratic support) have been used by Norris $(2012,1999)$ and others (Klingemann 1999; Qi and Shin, 2011) to identify "dissatisfied" or "critical democrats" who are seen to play a as a positive role in improving the quality of democracy. 
This is a peer-reviewed, accepted author manuscript of the following research chapter: Mattes, R. (2018). Support for democracy. In W. Thompson (Ed.), Oxford Research Encyclopedia in Politics (Oxford Research Encyclopaedias). [New York]: Oxford University Press. https://doi.org/10.1093/acrefore/9780190228637.013.622

\section{Do People Want Democracy?}

The research designs in either the Dahlian or Maslowian approaches use multi-item indices to tap underlying mental constructs and yield average decimalized index scores, often expressed in standardized terms. Thus, few scholars have attempted to generate population estimates of the actual proportion of citizens with the appropriate democratic attitudes or values. But the societies that cluster at the high end of these indices invariably tend be wealthier and located in North America or Western Europe. Similarly, Norris (2002) developed a social capital index, consisting of the percentage of people who trust others and the number of organizations to which the average citizen responded, and found that wealthier, and older democracies of northern Europe, North America, Australasia (but also South Korea, Taiwan, Dominican Republic) had relatively high levels of social capital.

Viewed through a Churchillian lens, most people in most countries say they support democracy and prefer it to other regime types. However, even in this more limited, "realist" sense, scholars obtain very different estimates depending on how survey questions are worded and framed. Using the responses to the questions in the World Values Survey, some scholars have concluded that support for democracy is uniformly high across the globe (e.g. Klingemann 2014 and 1999; Norris 2011; Inglehart and Welzel 2005; Welzel 2013). ${ }^{6}$ In the median country, for example, Inglehart (2003) reported that more than nine-in-ten people said that "having a democratic political system" is either "good" or "very good way of governing this country." Thus, he concluded that survey questions that use the "D-word" (democracy) or which ask about support for alternative types of political regimes generate "lip service" support for a "motherhood" concept. Others reached the same conclusion, though for a different reason. They point to various types of survey based investigations into how people understand democracy, and conclude that popular understandings of the concept vary so widely that we cannot be sure of what people are saying when they answer questions about democracy (Carlin and Singer 2012; Shin and Kim 2016; Shin ORE).

However, a review of responses to the Churchill-type questions in 57 societies in four continents covered by the Global Barometer Surveys between 2004 and 2007 yielded profoundly different results with large cross-national, and cross-regional variation (Denemark et al., 2016). 
This is a peer-reviewed, accepted author manuscript of the following research chapter: Mattes, R. (2018). Support for democracy. In W. Thompson (Ed.), Oxford Research Encyclopedia in Politics (Oxford Research Encyclopaedias). [New York]: Oxford University Press. https://doi.org/10.1093/acrefore/9780190228637.013.622

For instance, while 85 percent of Botswanans and 84 percent of Venezuelans said that "democracy is always preferable", just 39 percent of Malagasy and 24 percent of Pakistanis said so. And though 82 percent of Southern Europeans supported democracy by the early 1990s (and still do), just 43 percent of South Asians did in 2005 surveys. And when the authors examined responses to questions about authoritarian alternatives to democratic government, such as a oneparty state, military rule, or presidential dictatorship, support for democracy (measured as the rejection of these alternatives) was even lower in many places. Indeed, a surprisingly large number of people in many post-authoritarian societies approve of, or at least fail explicitly to reject authoritarian alternatives to democracy. For example, 63 percent of Sri Lankans and Nepalese and 26 percent of Jordanians actively approved of a strong leader who does not have to bother about elections, while nearly half of Bangladeshis (45 percent) and Pakistanis (49 percent) approved of military rule (for similar conclusions about the uneven nature of support in East Asia, using a relatively different battery of items, see Shin and Kim 2016).

\section{FIGURE 1 ABOUT HERE}

The same large differences in estimates, and thus conclusions about public attachment to democracy in many countries, can be seen in Figure 1. It compares the most recent responses to two questions asked by different survey projects in the same set of 40 countries between 2010 and 2014. While both questions explicitly refer to democracy, they are framed quite differently. Evidently, survey items and constructs which use the "D word" do not automatically tap invalid "motherhood" responses to socially desirable concepts. While the World Values Survey item that asks people to agree or disagree with a positive statement about democracy yields consistently high levels of agreement (over 70 percent in each country, and over 80 percent in most, the Global Barometer Surveys question that explicitly offers respondents simple, but apparently important alternatives, such as "whether or not we live in a democracy does not matter to a person like me," finds levels of support that are consistently lower, sometimes by more than 30 percentage points, and that vary widely from a high of 80 percent to a low of 36 percent. 
This is a peer-reviewed, accepted author manuscript of the following research chapter: Mattes, R. (2018). Support for democracy. In W. Thompson (Ed.), Oxford Research Encyclopedia in Politics (Oxford Research Encyclopaedias). [New York]: Oxford University Press. https://doi.org/10.1093/acrefore/9780190228637.013.622

\section{Are Publics Becoming More or Less Supportive?}

As important as it is, the extent of popular support for democracy only takes us so far. Perhaps a more important question is whether the scope of public support (as variously measured) has increased over time, or at least not retracted. The most recent analysis of GBS results (Denemark et al 2016) suggests that despite cross-national differences, the trajectories of public attitudes, as of 20XX -- were moving in the "right" direction in all but one of the democratizing regions for which longitudinal data were available at that point. Public support for democracy rose very rapidly in Southern Europe in the 1980s and has remained at very high levels. Support for democracy and rejection of authoritarian rule had also increased over time - though more modestly - in Central and Eastern Europe, Latin America, and sub-Saharan Africa. In East Asia, however, support for democracy declined in four of the six countries included in the first two rounds of the East Asia Barometer. And analyzing the results to WVS questions in 49 countries from 1995 to 2014, Steenekamp and Du Toit (2017) found that while support for democracy ("having a democratic political system" is a "very" or "fairly good of governing this country") remained very high (around nine in ten), support for expert rule, military rule, and presidential dictatorship all increased by four to five percentage points.

In sharp contrast to this picture of global stability, Robert Foa and Yascha Mounk (2016, 2017) claimed to find "signs of deconsolidation" in Americans' and West Europeans' responses to these and other WVS questions. The proportions who thought democratic rule was a "bad" way of governing the country, for instance, or who supported non-democratic alternatives, such as military rule, while still at low levels, had risen sharply, while the proportions who said it was "important" to live in a democracy had fallen. Moreover, they claimed, both trends were far more pronounced amongst the most recent generations. Given the anti-democratic trends that had been taking place in places like Turkey, Philippines, Poland and Hungary, combined with the British electorate's vote to leave the European Union and the American public's election of Donald Trump, these claims attracted both widespread attention and sharp scholarly response. Critics charged that the authors had made selective use of questions and response categories, and that the absolute size of any declines, and of age differences therein were quite modest (Goa 2015; Voeten 2017; Alexander and Welzel 2017). Others pointed out that the reported age 
This is a peer-reviewed, accepted author manuscript of the following research chapter: Mattes, R. (2018). Support for democracy. In W. Thompson (Ed.), Oxford Research Encyclopedia in Politics (Oxford Research Encyclopaedias). [New York]: Oxford University Press. https://doi.org/10.1093/acrefore/9780190228637.013.622

differences were likely due to long-apparent life-cycle effects, rather than generational erosion (Voeten 2017). And while millennials did express weaker approval of democratic value in Anglo-American democracies, the trend was not consistent in other western democracies (Norris 2017). Indeed, Voeten (2017) found no systematic decline across a range of established democracies over a twenty-year period. Perhaps the most telling response came from Alexander and Welzel (2017) who argued that the focus on the changes in percentages missed the fact that younger people are increasingly more likely to link their support for democracy to a liberal understanding of what democracy entails, than older respondents (Alexander and Welzel 2017). This reflected a more fundamental finding of those working within the Dahlian and Maslowian approach that there have been important qualitative changes in citizens values over the past several decades with citizens adopting less allegiant, and more assertive stances toward political authority (Dalton and Shin 2014).

\section{Where Does Support Come From?}

In contrast to economic theories of democratization which see the demand for democracy emanating from the poor and working class as a tool against the middle class, almost all studies have found that support - at least in the democratizing world -- is greatest amongst those with higher levels of education, who use news media, and have higher levels of cognitive engagement with politics. And most studies also find support to be higher in urban areas, and amongst men. The cognitive basis of democratic citizenship can also be seen in a related finding: people who understand see democracy in political, procedural or liberal terms are more supportive, whether measured as regime preferences (Bratton et al 2005; Mattes and Bratton 2007; Mattes et al. 2016; Alexander and Welzel 2017) or as self-expression or emancipation values (Welzel and Inglehart 2009;).

But, as anticipated by the Easton framework, support for democracy also tends to have a significant instrumental, or "specific" nature to it. But while the common scholarly wisdom expected support to hinge on public satisfaction with the economy (e.g. Przeworski et al, 199X), a range of studies on different continents agree that the instrumental nature of support tends to be driven by political factors, as much as or more than economic factors, including the quality of the 
This is a peer-reviewed, accepted author manuscript of the following research chapter: Mattes, R. (2018). Support for democracy. In W. Thompson (Ed.), Oxford Research Encyclopedia in Politics (Oxford Research Encyclopaedias). [New York]: Oxford University Press. https://doi.org/10.1093/acrefore/9780190228637.013.622

electoral process, the level of political freedom, the level of corruption, and the trustworthiness of representative and state institutions (Evans and Whitefield, 1995; Diamond, 1999; Rose et al. 1998; Bratton et al., 2005; Mattes and Bratton, 2007; Denemark et al., 2016). This is perhaps best illustrated by the long time series of data collected in post-authoritarian Spain where high levels of support for democracy have endured, even in the face of two separate periods of economic crisis (1981-1982, and again in 2008), with sharp rises in unemployment and inflation (Gunther and Montero 2016).

\section{What Does Support Do?}

Beyond its extent, and recent trends, the ultimate question that concerns us is whether support for democracy has anything to do with the stability or quality of a democratic political system. Unfortunately, we have no clear answer. At the micro level, there are some signs that democratic attitudes are indeed linked to potentially pro-democratic behaviors. Both Welzel (2007) and Qi and Shin (2012), for instance, found, respectively, that those who hold "liberty values" or are "dissatisfied democrats" (who both support democracy, but are also dissatisfied with the way it works) are more likely to sign petitions, or take part in boycotts and demonstrations. However, there is no reason to conclude that those actions were necessarily taken in support of, or in defense of democracy. Bratton et al. (2005) presented respondents with a range of potential steps that an anti-democratic leader might take against democracy, and found that Africans with higher levels of support for democracy were more likely to oppose such a leader, and say they would take specific actions to defend democracy. Yet these findings are limited by the hypothetical nature of the questions and responses.

The clearest link between democratic attitudes and pro-democratic behavior comes from an inventive study carried out by James Gibson (1997). He had just finished a survey of Russians' democratic values when the Soviet military staged an unsuccessful coup d'etat. He reinterviewed these respondents asking them whether they had supported or opposed the coup, and whether they had taken any actions for or against. The evidence was clear: those Russians who were most supportive of democratic institutions in the original survey were much more likely to have supported the anti-putsch faction, and also more likely to report having taken some specific 
This is a peer-reviewed, accepted author manuscript of the following research chapter: Mattes, R. (2018). Support for democracy. In W. Thompson (Ed.), Oxford Research Encyclopedia in Politics (Oxford Research Encyclopaedias). [New York]: Oxford University Press. https://doi.org/10.1093/acrefore/9780190228637.013.622

action in support (ranging from simply talking to someone else about the unfolding events to participating in anti-coup protests). While attitudes to protest were the strongest predictor, democratic values were clearly linked to pro-democracy protest.

We also have evidence that attitudes to democracy can guide voting behavior where explicit anti-system political parties exist. In their analysis in seven new democracies in Latin America and Southern Europe, Richard Gunther and his colleagues (2007) found that respondents who did not prefer democracy were significantly more likely to report having voted for political parties or candidates linked to the old autocratic regime (in Spain, Bulgaria and Chile) or to explicitly anti-democratic parties (Italy). In contrast, those who were dissatisfied with democracy simply voted against the ruling party, regardless of the democratic bona fides of the party in power. Importantly, subsequent rounds of CNEP surveys could find no such link because there were no political parties in the countries under study with any tangible linkages to the old regime or explicitly anti-democratic platforms (Mattes et al. 2016).

At the macro level, we have conflicting evidence as to whether aggregate public opinion is sufficiently powerful to shape the nature of the political regime. Early claims about the link between democratic stability and a peculiar mix of Dahlian personality attributes, what Almond and Verba (1962) called the "civic culture," were inconclusive because the study was based on only five countries.. At the same time, Booth and Seligson (1994) challenged this account by illustrating inconsistencies in the democratic record of Costa Rica, Mexico and Nicaragua and their citizens' relative levels of support for democratic processes.

Putnam's (1993) regional comparison within Italy argued that differing civic traditions in the north versus the south manifested themselves in differing levels of social capital, which produced very different qualities of governance. While limited to a comparison of two regions, he appeared to identify a "silver bullet" that might generate effective and accountable governance, and the study had a major impact on democracy advocates and donor organizations in the mid- to late-1990s, many of whom initiated new programs to "build social capital." Norris (2002) subjected this claim to cross-national analysis and found strong macro-level correlations between levels of social capital and subsequent levels of wealth and democracy. Yet she remained "strictly agnostic" about the causal direction between these associations, 
This is a peer-reviewed, accepted author manuscript of the following research chapter: Mattes, R. (2018). Support for democracy. In W. Thompson (Ed.), Oxford Research Encyclopedia in Politics (Oxford Research Encyclopaedias). [New York]: Oxford University Press. https://doi.org/10.1093/acrefore/9780190228637.013.622

acknowledging that it was equally likely that trust may be produced by wealth, and by previous democratic experience, or that they are all commonly driven by other forces, such as social modernization.

In contrast, the Maslowian image has received far more extensive cross-national testing, yet has remained the object of continuing debate. In various studies, Inglehart and Welzel claimed that that a country' level of "self-expression," "liberty" or "emancipation" values measured at a given point in time accounted for anywhere from one-half to three-quarters of the variance in subsequent changes in level of democracy across a large number of cases, even after controlling for factors such as a country's level of economic development and subsequent experience with democracy (Inglehart and Welzel 2010, 2005, 2003; Welzel and Inglehart 2009, 2006; Welzel 2013, Welzel and Moreno, 2014; Welzel et al., 2016). Yet the name of the value index changed frequently, as did the composition of the index and overall model, as Inglehart and Welzel responded iteratively to a series of critics who argued that once better measures of democracy, time lags, and country-specific effects were taken into account, the statistical impact of values disappeared (Hadenius and Teorell 2005; Teorell and Hadenius 2006; Dahlum and Knutsen 2016). Indeed, Dahlum and Knutsen (2016) argued that the data suggested that values were a product of prior levels of democracy rather than a cause.

Implicit in the Inglehart analysis has been the contention that implicit values (variously labelled) are far more important determinants of system-level democracy than explicit regime preferences. In one of their early analyses, for instance, they showed that while the proportion of respondents who told WVS interviewers that "having a democratic government" would be a "bad way" to govern a country was indeed strongly related to subsequent system level changes in the level of democracy, a country's aggregate self-expression value score both explained a considerably greater proportion of variation (Inglehart and Welzel, 2003). Other studies also failed to find any significant impact of explicit democratic preferences, whether measured by WVS (Hadenius and Teorell 2005; Teorell and Hadenius 2006; Qi and Shin 2011), or by the Barometers surveys (Fails and Pierce 2010). Yet as their arguments evolved over time in response to their critics, regime preferences have begun to make their way back into their analysis. Dalton and Welzel (2014) have shown how emancipative values leads to higher levels 
This is a peer-reviewed, accepted author manuscript of the following research chapter: Mattes, R. (2018). Support for democracy. In W. Thompson (Ed.), Oxford Research Encyclopedia in Politics (Oxford Research Encyclopaedias). [New York]: Oxford University Press. https://doi.org/10.1093/acrefore/9780190228637.013.622

of respondents' desire to live in a democracy, a liberal understanding of democracy, and more critical views of democratic performance. More importantly, Welzel and Klingemann (2010) show that "substantive demand for democracy" (those who both prefer a democratic regime and hold emancipative values) explains three quarters of subsequent levels of democracy. And most recently, Alexander and Welzel (2017) claim that countries with larger proportions of citizens who prefer democracy and have a liberal understanding of democracy, and who hold liberal sexual values, are more democratic, and more liberally democratic.

And from outside the Maslowian perspective, Qi and Shin (2011) have demonstrated that preferences for democracy and rejection of authoritarianism matter, but only when that support is matched with a sense of dissatisfaction with the way democracy is working. Using a sample of 46 "transitional regimes" which excludes established western democracies, they found that the proportion of dissatisfied democrats (counted as those who scored above the median on both a scale of support and rejection, and below the median on a scale of satisfaction with democracy and confidence in government, legislature, and political parties) was strongly related to subsequent levels of democracy, and had an even stronger impact on the extent of change in the level of democracy, even after controlling for a range of country level factors -- including that country's self-expression value score. Thus, they conclude, effective demand for democracy only arises from dissatisfied democrats. While congruence theory may account for (in)stability, "it is a sense of democratic deficit or deprivation that can directly trigger citizen participation in such democratic movements. Critical democrats experience such a sense of democratic deficit" (Qi and Shin 2011:256)

\section{Conclusion}

So are democrats critical to democracy, and if so, how? We have some tantalizing evidence at the micro level that democrats do in fact do things that help defend and deepen democracy. And at the macro level, there is a hint that aggregate democratic preferences leavened either with liberal values, a liberal understanding of democracy and, or a critical view of democratic performance, propel democracy forward. However, at this point, the safest answer is that the jury is still out. 
This is a peer-reviewed, accepted author manuscript of the following research chapter: Mattes, R. (2018). Support for democracy. In W. Thompson (Ed.), Oxford Research Encyclopedia in Politics (Oxford Research Encyclopaedias). [New York]: Oxford University Press. https://doi.org/10.1093/acrefore/9780190228637.013.622

There are several different issues we need to address before the jury can conclude its deliberation. First of all, we need to think more deeply about which image of the ideal democrat is the appropriate one. To do this, we need greater clarity as to whether mass support for democracy is necessary for democracy to occur or endure (ala congruence theory) or whether it simply increases the probability of democracy occurring or deepening (a theory of supply and demand). Moreover, we need to be clearer about when we expect public attitudes to matter: do they de-legitimate autocracies and push them toward democracy, deepen established democracies, or defend vulnerable democracies against autocratic entrepreneurs - or all of the above? We also need deeper thinking about who it is that needs to be democratic? It seems obvious that levels of support should not only be high, but also broad, cutting across key partisan, economic and social cleavages. But it could easily be true that a new democracy can withstand lower levels of support so long as it is concentrated amongst the most active and articulate opinion leaders, or amongst the supporters of governing parties.

But most importantly, we have far too little specification of exactly how support translates into democracy. Do democrats drive the process of democratization process by signing petitions, or joining boycotts, protests or social movements? Or do they give life to existing democratic systems through civic engagement and political participation? Or, do they protect democracy against erosion or breakdown by not voting for anti-democratic candidates, or by defending democracy through forms of peaceful collective action? Or - as most of our models implicitly assume - do citizens deter elite attempts to curtail democratic practice simply by holding pro-democratic orientations and creating a climate in which strategic politicians see little space to retract democratic practice? Finally, regardless of whether we see support for democracy as necessary for democracy, or only increasing its probability, in neither case does anyone see pro-democratic public attitudes as sufficient. Thus, we also need to pay attention to how support interacts with other elite or institutional factors. For example, can high levels of mass support compensate for weak elite preferences for democracy (Mainwaring and PerezLinan 2013), or must they both be high? And are mass attitudes more influential when filtered through legislators elected on the basis of a personal vote in single member districts, or through disciplined political parties elected by proportional representation? Alternatively, can strong 
This is a peer-reviewed, accepted author manuscript of the following research chapter: Mattes, R. (2018). Support for democracy. In W. Thompson (Ed.), Oxford Research Encyclopedia in Politics (Oxford Research Encyclopaedias). [New York]: Oxford University Press. https://doi.org/10.1093/acrefore/9780190228637.013.622

court systems or activist civil society organizations compensate for low levels of public support? Depending on our answers to questions such as these, it may not be very useful to continue regressing a given measure of democracy, or of change in democracy, on a single set of mass values or preferences across a large number of countries with vastly differing histories of democracy, and at different stages of democratic development. Rather, testing these possibilities will require the inclusion of new sets of variables, and might require radically different designs, examining differing sets of cases, and using differing time lags. Until then, it is likely that our understanding of public support for democracy will remain weakest at the spot where it matters the most.

\section{References}

Aleman, J. and Woods, D. 2016. "Value Orientations from the World Values Survey: How Comparable Are They Cross Nationally?” Comparative Political Studies 49(8): 10391067.

Almond, G., and Verba, S. 1963. The Civic Culture: Political Attitudes and Democracy in Five Nations. Princeton: Princeton University Press.

Anderson, Christopher, Andre Blais, Shaun Bowler, Todd Donavan and Ola Listhaug. 2005. Losers' Consent: Elections and Democratic Legitimacy. New York: Oxford University Press, pp. 311-332.

Aarts, K., Van Ham, C., and Thomassen, J. 2016. "Modernization, Globalization and Satisfaction with Democracy." In Myth and Reality of the Legitimacy Crisis: Explaining Trends And Cross National Differences in Established Democracies, Van Ham, C., Thomassen, J., Aarts, K., and Andeweg, R., eds. Oxford: Oxford University Press, pp. 37-58.

Aarts, K., Thomassen, J. and Van Ham, C. 2014. "Globalization, Representation, and Attitudes Toward Democracy." In Elections and Representative Democracy: Representation and Accountability, Thomassen, J. ed. Oxford: Oxford University Press.

Alexander, A. and Welzel, C. 2017. "The Myth of Deconsolidation: Rising Liberalism and the Populist Reaction." Journal of Democracy (Web Exchange).

Booth, J. and Seligson, M. 1994. "Paths to Democracy and the Political Culture of Costa Rica, Mexico and Nicaragua." In Political Culture and Democracy in Developing Countries, Diamond, L. ed. Boulder, Co.: Lynne Rienner Press, pp. 99-130. 
This is a peer-reviewed, accepted author manuscript of the following research chapter: Mattes, R. (2018). Support for democracy. In W. Thompson (Ed.), Oxford Research Encyclopedia in Politics (Oxford Research Encyclopaedias). [New York]: Oxford University Press.

https://doi.org/10.1093/acrefore/9780190228637.013.622

Bratton, M and Mattes, R. 2001. Support for Democracy in Africa: Intrinsic or Instrumental? British Journal of Political Science 31(3): 447-74.

Bratton, M., Mattes, R. and Gyimah-Boadi, E. 2005. Public Opinion, Democracy and Market Reform in Africa. Cambridge: Cambridge University Press.

Carlin, R. and Singer, M. 2011. "Support for Polyarchy in the Americas." Comparative Political Studies 44(11): 1500-1526.

Dahl, R. 1989. Democracy and It Critics. New Haven: Yale University Press.

1971. Polyarchy. New Haven: Yale University Press.

Dahlum, S. and Knutsen, C.H. 2016. "Democracy by Demand? Reinvestigating the Effect of Self-Expression Values on Political Regime Type." British Journal of Political Science 47: 437-461.

Dalton, R. and Shin, D.C., eds. Citizens, Democracy and Markets Around the Pacific Rim: Congruence Theory and Political Culture. Oxford: Oxford University Press.

Diamond, L. 1999. Developing Democracy: Towards Consolidation. Baltimore: Johns Hopkins University Press.

Denemark, D., Mattes, R. and Niemi, R. 2016. Growing Up Democratic: Does It Make A Difference? Boulder, Co.: Lynne Rienner Press.

Easton, D. 1965. A Systems Analysis of Political Life. New York: John Wiley and Sons.

Easton, D. 1957. "An Approach to the Analysis of Political Systems," World Politics 9(3): 383400.

Eckstein, H. Division and Cohesion in Democracy: A Study of Norway. Princeton: Princeton University Press.

Eckstein, H. 1961. A Theory of Stable Democracy. Princeton: Woodrow Wilson School of Public and International Studies.

Evans, G. and Whitefield, S. 1995. "The Politics and Economics of Democratic Commitment: Support for Democracy in Transition Societies." British Journal of Political Science 25(4): 485-513.

Fails, M. and Pierce, H.N. 2010. "Changing Mass Attitudes and Democratic Deepening." Political Research Quarterly 63(1): 174-187. 
This is a peer-reviewed, accepted author manuscript of the following research chapter: Mattes, R. (2018). Support for democracy. In W. Thompson (Ed.), Oxford Research Encyclopedia in Politics (Oxford Research Encyclopaedias). [New York]: Oxford University Press. https://doi.org/10.1093/acrefore/9780190228637.013.622

Finifter, A. and Mickiewicz, E. 1992. "Redefining the Political System of the USSR: Mass Support for Political Change." American Political Science Review 86:857-74.

Foa, R.S. and Mounk, Y. 2016. “The Democratic Discontent.” Journal of Democracy 27(3): 517.

Foa, R.S. and Mounk, Y. 2017. "The Signs of Deconsolidation.” Journal of Democracy 28(1): 515.

Fuchs, D., Guidorossi, G. and Svensson, P. 1995. "Support for the Democratic System.” In Citizens and the State, Klingemann, H.D. and Fuchs, D. eds. Oxford: Oxford University Press, pp. 323-353.

Gibson, J. 1997. "Mass Opposition to the Soviet Putsch of August 1991: Collective Action, Rational Choice, and Democratic Values in the Former Soviet Union." American Political Science Review 91(3): 671-684.

Gibson, J., Duch, R. and Tedin, K. 1992. "Democratic Values and the Transformation of the Soviet Union.” Journal of Politics 54: 329-371.

Goa, J. 2015. "Debunking the Myth That Millenials Are Ushering in the End of the Western World." Washington Post, 2 December.

Gunther, R. and Montero, J.R. 2016. "Southern Europe: Elite-Led Culture Change.” In Growing Up Democratic: Does It Make A Difference? Denemark, D., Mattes, R. and Niemi, R. eds. Boulder, Co.: Lynne Rienner Publishers, pp. 25-62.

Gunther, R. and Torcal, M. 2007. "Democracy and Intermediation: Some Attitudinal and Behavioral Dimensions." In Democracy, Intermediation and Voting on Four Continents, Gunther, R., Montero J.R., and Puhle, H.J., eds. Oxford: Oxford University Press, pp. 2976.

Gunther, R., Sani, G. and Shabad, G. 1986. Spain After Franco: The Making of a Competitive Party System. Berkeley: University of California Press.

Hadenius, A. and Teorell, J. 2005. "Cultural and Economic Prerequisites of Democracy: Reassessing Recent Evidence.” Studies in In Comparative International Development 39(4): 87-106.

Inglehart, R. 2003. "How Solid Is Mass Support for Democracy: And How Can We Measure It?" PS: Political Science \& Politics 36(1): 51-57.

Inglehart, R. 2005. Modernization, Cultural Change, and Democracy. New York: Cambridge University Press. 
This is a peer-reviewed, accepted author manuscript of the following research chapter: Mattes, R. (2018). Support for democracy. In W. Thompson (Ed.), Oxford Research Encyclopedia in Politics (Oxford Research Encyclopaedias). [New York]: Oxford University Press. https://doi.org/10.1093/acrefore/9780190228637.013.622

Inglehart, R. 2010. "Changing Mass Priorities: The Link Between Modernization and Democracy." Perspectives on Politics 8/2: 5510567.

Inglehart, R. and Welzel, C. 2003. Political Culture and Democracy: Analyzing Cross-Level Linkage." Comparative Politics 36(1): 61-80

Inkeles, A. and Smith, D. 1974. Becoming Modern: Individual Change in Six Developing Nations. Cambridge: Harvard University Press.

Jamal, A. and Tessler, M. 2008. "Attitudes in the Arab World." Journal of Democracy 19(1): 97110.

Klingemann, H.D. 1999. "Mapping Political Support in the 1990s. A Global Analysis.: In Critical Citizens: Global Support for Democratic Governance, ed. P. Norris, pp. 31-56. Oxford: Oxford University Press.

Lagos, M. 1997. “Latin America’s Smiling Mask.” Journal of Democracy 8(3): 125-138.

Lane, J-E. and Wagschal, U. 2012. Culture and Politics. New York: Routledge.

Linz, J. and A. Stepan. (1996). Problems of Democratic Transition and Consolidation. Baltimore, MD.: Johns Hopkins University Press.

Listhaug, O., Aardal, B. and Ellis, I. 2009. "Institutional Variation and Political Support: An Analysis of CSES Data From 29 Countries.” In The Comparative Study of Electoral Systems, Klingemann, H.D. ed. New York: Oxford University Press.

Mainwaring, S, and Perez-Linan, A. 2013. "Lessons From Latin America: Democratic Breakdown and Survival.” Journal of Democracy 34(2): 123-137.

Maslow, A. 1943. “A Theory of Human Motivation.” Psychological Review 50(4): 370-96.

Mattes, R. with Munjani, S., Liddle, W. Shi, T., and Chu, Y.H. 2016. "Parties, Elections, Voters and Democracy." In Voting in Old and New Democracies, Gunther, R., Beck, P., Magalhaes, P. and Moreno, A., eds. London: Routledge, pp. 193-229. 2016.

Mattes, R., and Bratton, M. 2007. "Learning About Democracy in Africa: Awareness, Performance and Experience.” American Journal of Political Science 51(11): 191-217.

Miller, A, Reisinger, W. and Hesli, V. eds. 1993. Public Opinion and Regime Change: The New Politics of Post-Soviet Studies. Boulder Co.: Westview Press.

Morlino, L. and Montero, J.R. 1995. "Legitimacy and Democracy in Southern Europe." In The Politics of Democratic Consolidation: Southern Europe in Comparative Perspective, Gunther, R. ed. Baltimore: Johns Hopkins University Press. 
This is a peer-reviewed, accepted author manuscript of the following research chapter: Mattes, R. (2018). Support for democracy. In W. Thompson (Ed.), Oxford Research Encyclopedia in Politics (Oxford Research Encyclopaedias). [New York]: Oxford University Press. https://doi.org/10.1093/acrefore/9780190228637.013.622

Norris, P. 2017. “Is Western Democracy Backsliding? Diagnosing the Risks.” Journal of Democracy (Web Exchange).

Norris, P. 2011. Democratic Deficit: Critical Citizens Revisited. Cambridge: Cambridge University Press.

Norris, P. 2002. Democratic Phoenix. Cambridge: Cambridge University Press.

Norris, P. 1999. Critical Citizens: Global Support for Democratic Governance. Oxford: Oxford University Press.

Putnam, R., with Leonardi, R. and Nanetti, R. 1993. Making Democracy Work: Civic Traditions in Modern Italy. Princeton: Princeton University Press.

Pye, L. and Verba, S. 1965. Political Culture and Political Development. Princeton: Princeton University Press.

Reilly, J. and Zigerell, L.J. 2012. “Don’t Know Much About Democracy: Reporting Survey Data With Nonsubstantive Responses.” PS: Political Science and Politics July: 462-467.

Rose, R. 1997. Survey Measures of Democracy. Studies in Public Policy 294. Glasgow: Centre for the Study of Public Policy, University of Strathclyde.

Rose, R. and Mishler, R. 2001. Political Support for Incomplete Democracies: Realist Vs. Idealist Theories and Measures. International Political Science Review 22 (4): 303-320.

Rose, R., Mishler, W. and Haerpfer, C. 1998. Democracy and Its Alternatives: Understanding Post-Communist Societies. Baltimore: Johns Hopkins University Press.

Seligson, M. 2002. "The Renaissance of Political Culture, or the Renaissance of the Ecological Fallacy? Comparative Politics 34(3): 273-292.

Shin, D.C. and Kim, H.J. 2015. "Liberal Democracy as the End of History: Western Theories Versus Asian Realities.” Asian Journal of Comparative Politics X(X): X-XX.

Shin, D.C. and Qi, L. 2011. "How Mass Political Attitudes Affect Democratization: Exploring the Facilitating Role Critical Democrats Play in the Process." International Political Science Review 32(3): 245-262,

Steenekamp, C. and Du Toit, P. 2017. "The Evolution of Support for Democratic Regime Principles and Its Alternatives." Journal of Public Affairs 17(1-2): 1-12.

Teorell, J. and Hadenius, A. 2006. "Democracy Without Democratic Values: A Rejoinder to Welzel and Inglehart." Studies in Comparative International Development 41(3): 951111. 
This is a peer-reviewed, accepted author manuscript of the following research chapter: Mattes, R. (2018). Support for democracy. In W. Thompson (Ed.), Oxford Research Encyclopedia in Politics (Oxford Research Encyclopaedias). [New York]: Oxford University Press.

https://doi.org/10.1093/acrefore/9780190228637.013.622

Voeten, E. 2017. “Are People Really Turning Away From Democracy” Journal of Democracy (Web Exchange).

Welzel, C. 2007. "Are Levels of Democracy Affected by Mass Attitudes? Testing Attainment and Sustainment Effects on Democracy." International Political Science Review 28(4): 397-424.

Welzel, C. and Inglehart, R. 2009. "Political Culture, Mass Beliefs and Value Change.” In Democratization, Haerpfer, C., Bernhagen, P., Inglehart, R. and Welzel, C. Eds. Oxford: Oxford University Press, pp. 126-144.

Welzel, C. and Inglehart, R 2006 "Emancipative Values and Democracy." Studies in Comparative International Development 41: 74-94.

Welzel, C. and Inglehart, R, and Kruse, S. 2016. "Pitfalls in the Study of Democratization." British Journal of Political Science 46: 1-10.

Welzel, C. and Klingemann, H.D. 2010. "Democratic Congruence Re-Established: The Perspective of 'Substantive' Democracy.” In How Democracy Works: Political Representation and Policy Congruence in Modern Societies, Rosema, M., Denters, B., and Aarts, K. eds. Utrecth: Pallas Publications, pp. 89-114.

Welzel, C. and Moreno, A. 2014. "Enlightening People: The Spark of Emancipative Values.” In The Civic Culture Transformed: From Allegiant to Assertive Citizens, Dalton, R. and Welzel, C., eds. Cambridge: Cambridge University Press. 
This is a peer-reviewed, accepted author manuscript of the following research chapter: Mattes, R. (2018). Support for democracy. In W. Thompson (Ed.), Oxford Research Encyclopedia in Politics (Oxford Research Encyclopaedias). [New York]: Oxford University Press. https://doi.org/10.1093/acrefore/9780190228637.013.622

\section{Notes}

1 "Generally speaking, would you say that most people can be trusted or that you can't be too careful in dealing with people?"

${ }^{2}$ Now I am going to read off a list of voluntary organizations. For each one, could you tell me whether you are an active member, an inactive member, or not a member of that type of organization.”

3 "Which of the following statements do you agree with most? A) Democracy is preferable to any other kind of government. B) In certain situations, and authoritarian government can be preferable to a democratic one. C) To people like me, it doesn't matter whether we have a democratic government or a non-democratic government."

4 "Our current system of government is not the only one that this country has had. Some people say that we would be better off if the country was governed differently. What do you think? A) We should return to Communist rule? B) The army should govern the country? C) Best to get rid of Parliament and elections and have a strong leader who can quickly decide things. D) A return to monarchy would be better? E) The most important decisions about the economy should be made by experts and not the government and Parliament."

${ }^{5}$ The original version asked in Eurobarometer read: "On the whole, are you very satisfied, fairly satisfied, not very satisfied or not at all satisfied with the way democracy is developing in our country."

${ }^{6}$ The World Values Survey contains several questions that are intended to measure support for democracy.

"I am going to describe various types of political systems and ask what you think about each as a way of governing this country. For each would you say it is a very good, fairly good, fairly bad or very bad way of governing this country: having a strong leader who does not have to bother with parliament and elections; having experts, not government, make decisions according to what they think is best for the country; having the army rule; having a democratic system."

"I'm going to read off some things that people sometimes say about a democratic political system. Could you please tell me if you agree strongly, agree, disagree or disagree strongly, after I read each one of them? In democracy, the economic system runs badly; Democracies are indecisive and have too much quibbling; Democracies aren't good at maintaining order; Democracy may have problems but it's better than any other form of government." 